\title{
Comparação do desempenho em IATF de vacas Canchim e Nelore que conceberam no início e final da estação de monta anterior: Artigo
}

\author{
Bruno Fianco ${ }^{1}$, Denis Vinicius Bonato ${ }^{1}$, Julio Cezar Heker Junior ${ }^{1}$, Luiz Paulo Mendes Ferreira ${ }^{1}$, \\ Mateus Poczynek ${ }^{1}$, Talita Abreu Lacerda Brem ${ }^{2}$, Marlon Richard Hilário da Silva ${ }^{1}$, Pedro Paulo \\ Maia Teixeira $^{1}$
${ }^{1}$ Universidade Estadual do Centro-Oeste do Paraná (UNICENTRO), Guarapuava, PR-Brasil, e-mail: bruno.fianco@hotmail.com
${ }^{2}$ Médica Veterinária Autônoma.

ISSUE DOI: $10.3738 / 1982.2278 .1123$

A eficiência da produção de bezerros tem extrema importância para toda a cadeia produtora de carne bovina, pois é a base de todo o setor. No entanto, as taxas de prenhez dos rebanhos brasileiros ainda estão aquém do potencial reprodutivo das fêmeas bovinas, neste contexto, as melhorias no manejo e na nutrição associadas ao uso de biotecnologias, como a Inseminação Artificial em Tempo Fixo (IATF) são ferramentas que melhoram significativamente os índices reprodutivos do rebanho. Desta forma, o objetivo do presente trabalho foi avaliar a eficiência de um protocolo de IATF em vacas de corte. Foram utilizadas 127 fêmeas bovinas, divididas em 4 grupos, com distinção entre raças e a época de concepção dentro da estação de monta anterior. Os grupos foram: vacas Canchim que conceberam no início (GC1) ou final (GC2) da estação de monta anterior, e vacas Nelore que conceberam no início (GN1) ou final (GN2) da estação de monta anterior. Utilizou-se um protocolo de 3 manejos, no qual foi introduzido o implante intravaginal monodose (impregnado com $0,585 \mathrm{~g}$ de progesterona), e aplicou-se $2 \mathrm{mg}$ de benzoato de estradiol no primeiro dia 0 (D0). No dia oito (D8) os implantes foram retirados e foi aplicado 300 UI de Gonadotrofina coriónica equina (eCG), 37,5 $\mu \mathrm{g}$ de d-cloprostenol e $1 \mathrm{mg}$ de cipionato de estradiol. Após 48 horas (D10) foi realizada a IATF, 15 dias após a IATF as vacas foram agrupadas com touros testados para o repasse por 30 dias, em uma relação de 1 touro para cada 20 fêmeas. O diagnóstico gestacional foi realizado por meio de ultrassonografia 30 dias após o término do repasse, sendo a diferença entre a prenhez de IATF e touro feita através da avaliação do estágio de desenvolvimento do feto. A taxa de prenhez na IATF + Repasse dentro do grupo das que conceberam no início da estação de monta anterior foi de 93,753\% (15/16) para o GC1 e $84 \%$ (21/25) para o GN, no grupo das que conceberam no final da estação de monta anterior, houve $51,72 \%$ (15/29) para o GC2 e 50,88\% (29/57) para o GN2. Observou-se superioridade da raça Canchim em comparação a nelore, este fato pode ser explicado pela heterose genética das vacas Canchim, pois o cruzamento entre raças de origens distintas para produção de raças 
sintéticas, resulta em incremento na fertilidade dos animais. Também verificou-se grande diferença na taxa de prenhez em favor dos animais que conceberam no início da estação de monta anterior, quando comparado ao grupo contrário, confirmando que as vacas mais férteis concebem anteriormente, e por consequência, vem a parir no início da estação de parição, tendo um tempo adequado de recuperação entre o parto e o início da estação de monta, alcançando anualmente maiores taxas de prenhez, fato este que ocorre nos sistemas tradicionais que utilizam estação de monta.

Palavras-chaves: biotécnicas reprodutivas, histograma de parição, sincronização de estro, heterose, fertilidade. 